\title{
Effects of Prohexadione-Calcium on 'Monroe/GF 677' Peach Vegetative Shoot Growth, Fruit Yield and Quality
}

\section{Melike ÇETINBAŞ ${ }^{1}$ (i) Hasan Cumhur SARISU ${ }^{1}$ (i) Sinan BUTAR ${ }^{1}$ (i)}

${ }^{1}$ Fruit Research Instiute, 32500, Isparta, Turkey

\author{
Article History \\ Received 05 March 2021 \\ Accepted 15 June 2021 \\ First Online 29 June 2021
}

\section{Corresponding Author \\ E-mail: melikecetinbas@gmail.com}

\section{Keywords \\ Fruit firmness \\ Fruit size \\ Plant growth regulator \\ Prunus persica L. \\ Shoot length}

\begin{abstract}
Prohexadione-calcium (Pro-Ca) is a recently developed plant growth retardant used in some fruit trees. However, it is important that the reduction of vegetative shoot growth does not decrease yield and fruit quality. In this study, the effects of Pro-Ca applications on the vegetative growth and some fruit quality of the Monroe peach, growing on vigor rootstock (GF 677) were investigated. For this reason, trees were sprayed twice with 0 (water +

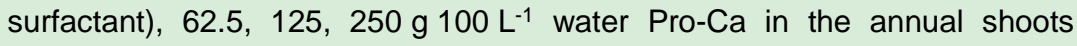
reached $5 \mathrm{~cm}$ within a three week interval in the spring of 2018 and 2019 years. Shoot length was decreased by $28-32 \%$ for shoots treated with Pro-Ca. The average internode length was significantly reduced for Pro-Ca-treated shoots. The lowest average internode length on the shoot was obtained with

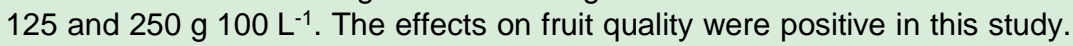

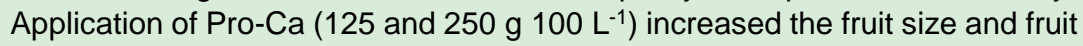
mass of cv. Monroe' peach. $250 \mathrm{~g} 100 \mathrm{~L}^{-1}$ Pro-Ca concentration led to firmer fruit relative to the other applications and control fruits. Two application 125 or

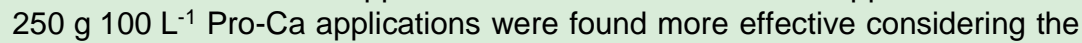
criteria investigated. The Pro-Ca applications were found to be effective in controlling the vegetative shoot growth and fruit quality in cv. Monroe/GF-677 peach.
\end{abstract}

\section{Introduction}

Prohexadione calcium (3, 5-dioxo-4propionylcyclohexanecarboxylic acid) is a plant growth regulator used by dioxygenase enzymes (GA20-oxidase and GA3-oxidase) for its ability to inhibit gibberellin biosynthesis (GAs) by blocking 3ß-Hydroxylation (Beam et al., 2002; Davies, 2004). Prohexadione calcium (Pro-Ca) was first tested in rice (Oryza sativa) and it was proven to shorten the length of rice by $66-78 \%$ by inhibiting gibberellic acid production (Nakayama et al., 1990). Pro-Ca, a research subject in rice, apples, pomes, petunias, and various vegetables, grain crops, etc. many products (Lee et al., 1998; Costa et al., 2004; Ilias and Rajapakse, 2005; Ergun et al., 2007; Kim et al.,
2007; Başak 2020; Treadway, 2020), is used extensively in fruit trees, especially by apple producers, instead of mechanical pruning. As it is known, mechanical pruning is a cultural practice with a lot of labor and cost every year (Byers and Yoder 1999; Costa et al., 2001; Uselis et al., 2020; Treadway, 2020). In recent years, the use of Pro-Ca plant growth regulator has increased gradually in terms of decreasing the labor intensity, as orchards have been started to be established by using high density planting and different training systems in other fruit types besides apples. Kaur et al. (2020) applied Pro-Ca (100, 200, $\left.400 \mathrm{mg} \mathrm{L}^{-1}\right)$ and Paclobutrazol (100, 250, $\left.500 \mathrm{mg} \mathrm{L}^{-1}\right)$ plant growth regulators to the leaves of the pear varieties 'Patharnakh' and 'Punjab Beauty' that they grow 
with the $\mathrm{Y}$-Trellis training system and high density planting, thus preventing vegetative growth and the workload by requiring less mechanical pruning. They reported that it decreased considerably, especially in orchards with high density planting and especially the application of $400 \mathrm{mg} \mathrm{L}^{-1}$ Pro-Ca gave the best results in both low shoot growth and fruit quality. Although Pro-Ca applications have been tested on both vegetable seedlings and fruit trees, the number of researches for peach is almost non-existent. Byers and Yoder (1999) reported that application of Pro-Ca had not effect on shoot length or fruit quality in 'Redhaven' peach and its data were not recorded. However, in most European countries, peach orchards are established as high density planting, which increases the more labor in both mechanical pruning and thinning. In Turkey, the cultivation of peach is increasing with high density planting and also with new training systems. Peach production in Turkey $6^{\text {th }}-7^{\text {th }}$ in the world in previous years. It ranks $5^{\text {th }}$ in the world with 789457 tons according to the latest data (FAO, 2020). Peach produced in nurseries in Turkey are on peach seedlings (85\%) or more GF 677 rootstocks $(10 \%)$. However, the use of tall trees results in lower labor efficiency (harvest, pruning, and thinning), and higher use of agro-chemicals per hectare. In addition, it is necessary to reduce the labor force and cost in pruning in peach orchards that are high density planted with new training systems (Hossain et al., 2006). Plant height reduction is playing an important role promoting both yield and quality, and in decreasing cost, area and labor (Hayashi et al., 2001; Karlovic et al., 2004). For this reason, it is important that reduction of this peach tree's vegetative shoot growth concentrations not decrease the yield and fruit quality. So far in Turkey and in the world, some chemicals used in pruning peach trees gibberellin inhibit the biosynthesis of plant growth regulators (chlormequat chloride, daminozide, mefluidide, paclobutrazol, etc.), were studied. It has been reported that these practices prevent shoot development but have no negative or no effect on fruit quality (Davis et al., 1991; Bilginer et al., 1995). However, Pro-Ca, which is used for chemical pruning of fruit types such as apple and pear, has not been studied in peach. Therefore, the main purpose of this research is to determine the efficiency of Pro-Ca plant growth regulator as chemical pruning instead of mechanical pruning. The other purpose of this research was to determine the optimum concentrations in the application of Pro-Ca for controlling the vegetative growth of peach trees, as well as the effects of Pro-Ca on fruit quality.

\section{Material and Methods}

The experiments were carried out in the Fruits Research Institute (Eğirdir, Isparta, Turkey, 37 $49^{\prime}$ $\mathrm{N}$ latitude and $30^{\circ} 52^{\prime} \mathrm{E}$ longitude and $926 \mathrm{~m}$ above sea level) between 2018 - 2019. To determine the effect of Pro-Ca on vegetative growth control and fruit quality parameters of peaches (Prunus persica L.). Uniform 6-years old 'Monroe' peach trees grafted on GF 677 rootstocks $(5 \times 3 \mathrm{~m})$ were selected and grouped into four blocks with 32 trees in each, based on proximity in the orchard and crop load. The experimental design was a randomized block, with four treatments and four replicates, using a double tree for each treatment. The trees were trained to an open vase and pruned in early spring, and standard cultural practices had been used on the trees for several years. The trees were sprayed twice with 0 (water + surfactant), 62.5, 125,

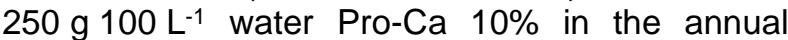
shoots $5 \mathrm{~cm}$ within a three week interval in the spring ( $1^{\text {st }}$ and $2^{\text {nd }}$ years). All the spray solutions contained 'Spur' as a surfactant $\left[1 \%, v^{-1}\right.$ (SumiAgro, Turkey)]. The pulverized treatments were applied with a low pressure hand sprayer.

\subsection{Assessment of vegetative growth}

The following measurements of plant growth were made during the two seasons of study after autumn leaf fall.

Tree height $(\mathrm{cm})$ : The distance from the grafting point of the trees in each application to the tip of the peak branch was measured with a tape measure.

Tree width $(\mathrm{cm})$ : The distance from the shoulder level of the canopy of the trees in each application to the tip of the end shoots on both sides parallel to the ground was measured with a tape measure.

Trunk diameter $(\mathrm{mm})$ : The trunk diameter of the trees in each application, which is $10 \mathrm{~cm}$ high from the grafting point, was measured with a caliper.

Average number of shoots: One-year shoots of the trees in each application were counted and recorded.

Average length of annual shoots $(\mathrm{cm})$ : The length of three shoots taken from four directions of the trees was measured with a ruler.

Average diameter of annual shoots $(\mathrm{mm})$ : The diameters of three shoots taken from four directions of the trees were measured with calipers from the middle part.

Average number of nodes and average internode length on shoots $(\mathrm{cm})$ : The internodes of three shoots taken from four directions of the trees in each application were counted and the average internode length was found by dividing the total node number by the shoot length.

Shoots crotch angle $\left({ }^{\circ}\right)$ : The angle of each shoot with the main branch of three shoots taken from four directions of the trees in each application was recorded.

Phytotoxicity and side effects: Macroscopic observations were made on the shoot, leaves and fruit a few days after the application and until the end of the experiment in order to determine the phytotoxic effects of Pro-Ca applications on leaves, shoots and fruits. In addition, it was observed 
whether the applications had an effect on bee activity.

\subsection{Assessment of fruit yield and quality}

Yields belonging to all applications were obtained by gathering fruits at the appropriate harvest time and weighing $\left(\mathrm{kg}^{\mathrm{t}} \mathrm{tree}^{-1}\right)$. Some fruit quality characteristics were determined in 20 fruits taken from the lower and upper four sides of the tree from each repetition of each application. Fruit width and length $(\mathrm{mm})$ were measured with the help of a digital caliper, and fruit weight $(\mathrm{g})$ was measured with a digital scale with 0.01 precision. Fruit flesh firmness $(\mathrm{N})$ with Lyoyd Instruments LF Plus brand texture device using $8 \mathrm{~mm}$ diameter tip. Fruit color determined with Model CR-300, Minolta in $L$ *, $a$ *, $b^{*}, C *$ and hue ${ }^{\circ}\left(h^{\circ}\right)$. The fruit surface color was made as $\%$ in the surface color formation on the fruit, and the evaluation was in the range of $1-100 \%$. The red fruit group was $100 \%$ and the lightest fruit group was considered as $1 \%$, and was examined by five separate panels. The water soluble solid content (SSC, \%) of the fruits was recorded with a digital refractometer (Palette PR-32 Atago)]. Titratable acidity (TA, \%) and $\mathrm{pH}$ were measured with an automatic titrator (Mettler Toledo T50).

\subsection{Statistical analysis}

The collected data were subjected to statistical analysis using a randomized complete block design. Statistical analyses were performed using SAS-JMP 8.0 package. Mean values were compared using LSD's multiple range test at $p<0.05$ level. Variables were presented as Mean and Standard deviation.

\section{Result and Discussion}

\subsection{Vegetative growth}

In the vegetative measurements which were held in the first year of Pro-Ca applications, it was determined that the tree height, tree width and the trunk diameter was insignificant statistically, but in the second year, it was determined that only the tree width was significant $(p<0.05)($ Table 1$)$. The tree width was increased in the second year and the maximum tree width was occurred in the

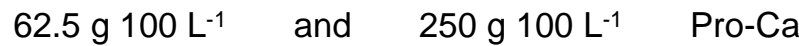
applications. When we consider the second year changes' in the tree widths and specially trunk diameters beside the first year, it was revealed that the trees continued to improve not lengthwise, but the in width. The reason of this result can be conceivable as the angles which the shoots made with the branches are increased. Thus, in the second year of our research, the angle that the shoots made with the branch was increased, which this situation is a needed physiological development in fruit growing as the Beyazit et al. (2012) also stated. The shoot pruning and bending processes provided the angles to widen creates a positive impact on flower buds, increases the fruit quality and controls tree development. In our research, the angle which shoot makes with the main branch was widened and hence, it was determined that the tree width was increased.

In the ANOVA, which was made on the shoot growth, Pro-Ca concentrations had no effect on the average number of shoots statistically in both years (Figure 1A). However, it had effect on the average length of shoots (Figure 1B; $P<0.05$ ). The length of shoots decreased compared to the control group in both years. In the first year, the least shoot length

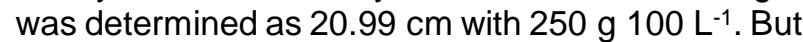
in the second year, it was $16.74 \mathrm{~cm}$ with

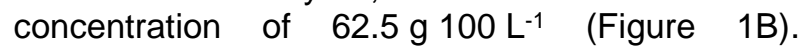
Statistically, the Pro-Ca concentrations on average diameter of shoots were significant in 2018, but were not in 2019. The average diameter of shoots increased with the Pro-Ca concentrations in 2018.

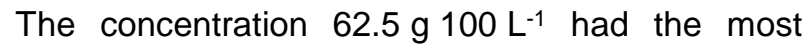
average diameter of shoots $(4.29 \mathrm{~mm}$ ) (Figure 1C). The shoot angles differences in applications was significant in $2018 \quad(P<0.05)$, but they were insignificant in 2019 (Figure 1D). However, the Pro$\mathrm{Ca}$ in the second year made wider angles than the first year. We can say that the applications which were made consecutively widened the shoots angles. In 2018, it was determined that the angle increases with the Pro-Ca concentrations increase as well, and the widest angle was in the use of

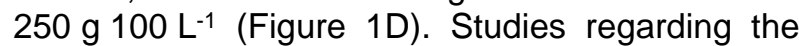
Pro-Ca were generally carried out to bring under control the vegetative development of the species such as apples (Schupp et al., 2003; Karlovic et al., 2004; Greene, 2008; Duyvelshoff and Cline, 2013;

Table 1. Effect of Pro-Ca on tree length, canopy width and trunk diameter in Monroe/GFF 677.

\begin{tabular}{lccrrrr}
\hline \multirow{2}{*}{\begin{tabular}{l} 
Pro-Ca concentrations $\left.100 \mathrm{~L}^{-1}\right)$ \\
\cline { 2 - 7 }
\end{tabular}} & \multicolumn{2}{c}{ Tree length $(\mathrm{cm})$} & \multicolumn{2}{c}{ Canopy width $(\mathrm{cm})$} & \multicolumn{2}{c}{ Trunk diameter $(\mathrm{mm})$} \\
\hline Control & $1^{\text {st }}$ year & $2^{\text {nd }}$ year & $1^{\text {st }}$ year & $2^{\text {nd }}$ year & \multicolumn{1}{c}{$1^{\text {st }}$ year } & $2^{\text {nd }}$ year \\
62.5 & $321.25 \pm 19.3$ & $263.50 \pm 0.11$ & $165.00 \pm 14.7$ & $214.25 \pm 0.20 \mathrm{ab}{ }^{*}$ & $66.56 \pm 12.5$ & $114.72 \pm 12.81$ \\
125 & $276.25 \pm 22.9$ & $285.00 \pm 0.17$ & $161.25 \pm 27.2$ & $239.00 \pm 0.13 \mathrm{a}$ & $54.63 \pm 3.01$ & $102.29 \pm 9.19$ \\
250 & $302.50 \pm 67.0$ & $264.25 \pm 0.10$ & $172.50 \pm 51.9$ & $195.50 \pm 0.26 \mathrm{~b}$ & $53.37 \pm 14.4$ & $91.68 \pm 7.48$ \\
\hline P values & $270.00 \pm 8.16$ & $255.00 \pm 0.24$ & $143.75 \pm 24.3$ & $233.00 \pm 0.23 \mathrm{a}$ & $55.08 \pm 2.90$ & $105.44 \pm 13.04$ \\
\hline
\end{tabular}

Data were mean \pm standard deviation.

Different letters indicate statistically significant differences among the treatments $(L S D, P<0.05)$. 

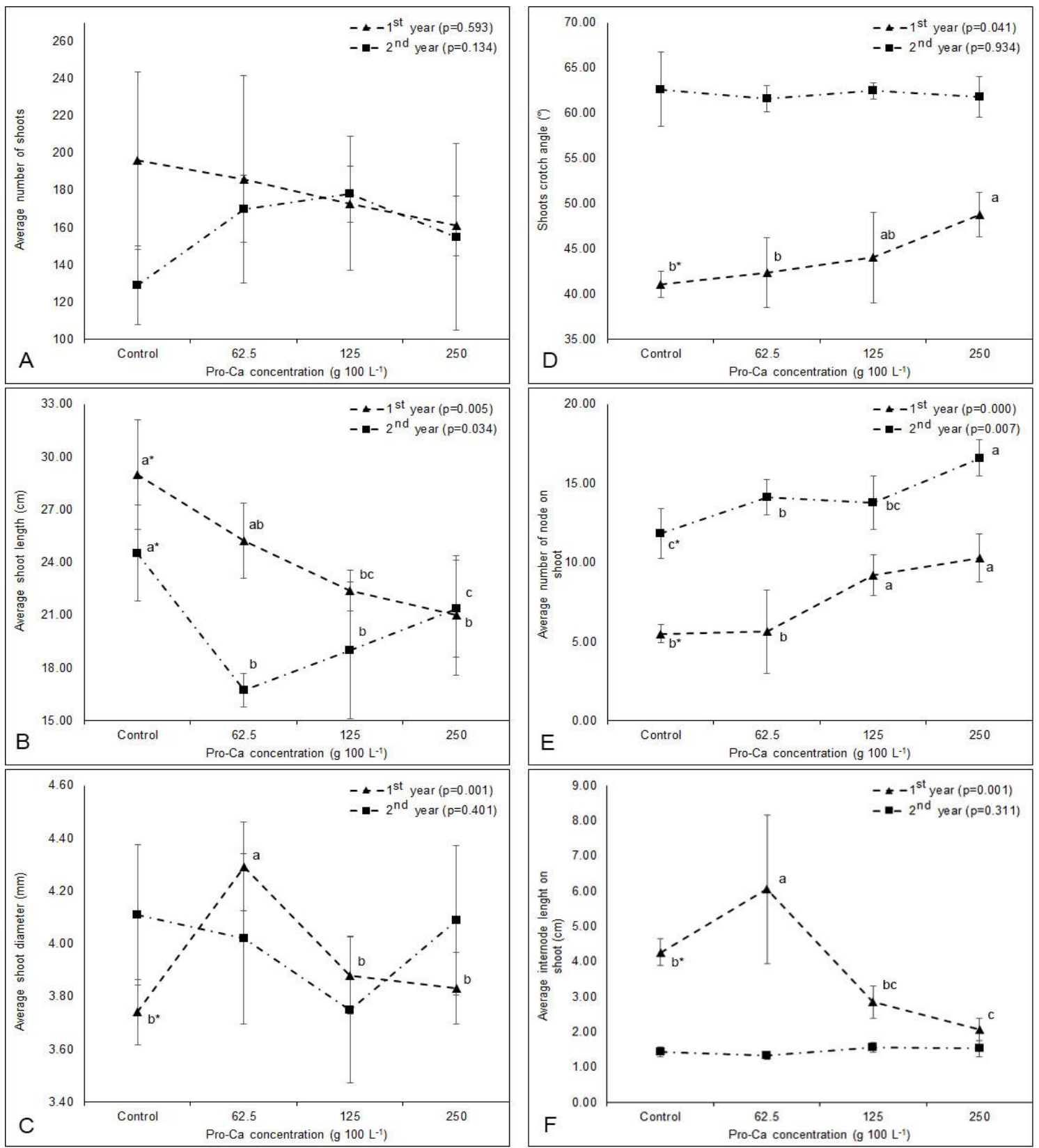

Figure 1. The effect of Pro-Ca implementations on Monroe/GFF 677 peach shoot growth (2018 and 2019).

Data were mean \pm standard deviation. Different letters indicate statistically significant differences among the treatments (LSD, $\mathrm{P}<0.05)$.

Amarante et al., 2020; Uselis et al., 2020), pears (Elfving et al., 2003; Sugar et al., 2004; Einhorn et al., 2014; Carra et al., 2017; Kaur et al., 2020), and vegetables (Kofidis et al., 2008; Özbay and Ergun, 2015; Başak, 2020), and also to partially downgrade the growth. However, no studies have been made for peach species, and in a study carried out it is observed that no data has been indicated. In current study, Pro-Ca reduced the average shoot length by $30 \%$ compared to the control group in the both years. Pro-Ca was effective statistically significant on node number $(\mathrm{P}<0.05)(2018-2019)$. In the both years, the average number of nodes increased in accordance with increasing Pro-Ca concentrations (Figure 1E).

The average internode lengths differences were statistically significant in the first year $(P<0.05)$, and insignificant in the second year. Internode lengths was inclined to decrease and increase in the both years. (Figure 1F). In the study, the average number of nodes was increased as the average lengths of shoots decreased. In accordance with our findings, Çetinbaş et al. (2015) noted that the average number of nodes increased and the length of internodes decreased with Pro-Ca in Strakrimson/MM111. This situation can be thought to increase fruit yield, with more flower buds.

\subsection{Phytotoxicity and side effects}

The macroscopic observations conducted on the shoots, the leaves and fruits a few days after application and until end of trial no phytotoxicity or side effect of Pro-Ca applications could be observed 
in both of the years. Besides, it was also determined that the application has no negative effect on bee activity.

\subsection{Yield and fruit quality}

The effect of Pro-Ca to yield was statistically significant in the both years $(P<0.05)$ (Figure $2 A)$. Yield increased with the applications, and the optimal yield was achieved with the $62.5{\mathrm{~g} 100 \mathrm{~L}^{-1}}^{-1}$ Pro-Ca concentration (23.38-27.04 kg tree $\left.{ }^{-1}\right)$ in the both years. The other high concentration yields, approximately the same values and in the same statistical group were found (Figure 2A). Kaur et al. (2020) reported that 'Punjab Beauty' and 'Patharnakh' pears exhibit a positive reaction to Pro$\mathrm{Ca}$ and increase in yield by $33 \%$ to $46 \%$ with the 200 and $400 \mathrm{mg} \mathrm{L}^{-1}$ concentrations due to the light which penetrates the trees. Hence, our findings demonstrated similar results and increase in the yield by $31 \%$ to $50 \%$ in the first year, and $31 \%$ to $43 \%$ percent were recorded.

The results of the ANOVA of one of the most important parameters for assessing fruit quality; fruit width, length, and weight, was statistically significant for the year $2018 \quad(\mathrm{P}<0.05)$, and insignificant for 2019 (Figure 2B, C, D). In the first year, Pro-Ca increased fruit size generally, except

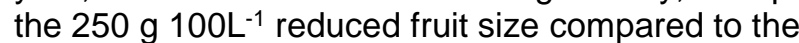
control group. Nonetheless, it was observed that this has no negative effects on fruit size effectively (Figure 2D).

In many studies in which Pro-Ca applications were carried out, different results indicated on fruit size (Costa et al., 2004; Medjdoub et al., 2004; Kaur et al., 2020). Similarly to our study, Schupp et al.

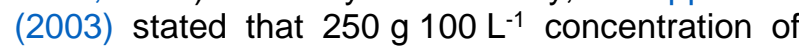
Pro-Ca to Empire apple reduced the weight of the fruit.

In the both years, it was found that Pro-Ca concentrations were statistically significant on the fruit flesh firmness $(P<0.05)$. It was identified that in the both years the highest concentrations considerably increased the fruit flesh firmness. While the lowest concentration $\left(62.5{\left.\mathrm{~g} 100 \mathrm{~L}^{-1}\right) \text { was }}^{-1}\right.$ identified to have the least firmness, it was in the same group with the control (Figure 2E). Also, SSC and TA in the year 2018 were also found to be significant $(P<0.05)$ (Table 2). In the first year,

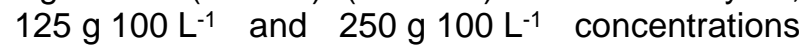
increased SSC and TA, and $62.5{\mathrm{~g} 100 \mathrm{~L}^{-1}}^{-1}$ concentration had almost the same values with the control group. In the both years application concentrations on $\mathrm{pH}$ had no difference from control (Table 2). In the 'Smith' pear, Pro-Ca had no effect on SSC, TA, pH and firmness (Carra et al., 2017). Moreover, Çetinbaş et al. (2015) reported that in 'Starkrimson' apple, Pro-Ca had no negative or positive effect on these fruit quality. As chemical pruning, experiments were carried out with different gibberellin biosynthesis inhibitors, which have the same mechanism of action as Pro-Ca. Mefluidide
(1000-2000 ppm) application in Camden peach was decreases the growth but decreases the fruit yield in the following year, Dikegulac (1000-1500 ppm) application decreased the growth but didn't not affect the fruit yield, Mepiquat chloride decreased the growth in the application year and flower bud formation in the following year, It was stated that PP528 (400 ppm) application was not effective on growth (Coston and Gambrell, 1983). Bilginer et al. (1995) stated that Paclobutrazol applied from the leaf is more effective on vegetative growth than Redhaven variety in Cardinal and Glohaven varieties, and emphasized that it decreased the shoot length per fruit eye and did not significantly affect the fruit quality. Pro-Ca applications we used in our study, on the other hand, were determined to reduce shoot development, increase fruit yield and not negatively affect fruit quality. Indeed, Prohexadione-Ca is known to interfere with the 3- $\beta$ hydroxylation of $G_{20}$ to $G_{1}$. The net effect is a reduction in immobile, biologically active $\mathrm{GA}_{1}$ and an increase in the levels of mobile, but inactive GA20 (Evans et al., 1999; Graebe, 1987).

Pro-Ca, which is used in appropriate doses according to the age and development of the tree, has a negative effect on the vegetative development, unlike the chemicals used in the past and started to be abandoned, it breaks down in a short time such as 4-5 weeks. Thus, it is called an environmentally friendly chemical due to its ease and speed. Pro-Ca, which performs an agropetal (bottom-up) transport within the plant, thus does not affect other organs other than the vegetative component applied. Pro-Ca is fully absorbed by the plant within 8 hours after application to the leaves (Evans et al., 1997).

When Pro-Ca effect on fruit color, one of the most important quality parameters of the fruit peach, was assessed; $L^{*}, a^{*}, b^{*}, C^{*}$ and $h^{\circ}$ values were statistically significant in $2018 \quad(P<0.05)$, and insignificant in 2019 (Figure 3A, B, C, D, E). Brightness $\left(L^{*}\right)$ and yellowness $\left(b^{*}\right)$ were reduced by the applications in 2018. The control group fruits had the highest $L^{*}$ and $b^{*}$ values (Figure $3 A, C$ ). $a^{*}$ values meaning there was more forming of the color red increased with the Pro-Ca. $62.5{\mathrm{~g} 100 \mathrm{~L}^{-1}}^{-}$ concentration realized with the highest $\mathrm{a}^{*}(29.27)$ value. (Figure $3 \mathrm{~B}$ ). $\mathrm{C}^{*}$ value indicating color density increased with Pro- $\mathrm{Ca}$, and $\mathrm{h}^{\circ}$ value indicating color reduced (Figure 3D, E). As the $\mathrm{C}^{*}$ color indicates the color density, the application with the densest color was acquired through the use of $125 \mathrm{~g} 100 \mathrm{~L}^{-}$ ${ }^{1}$ concentration (Figure 3E). In 2019, with Pro-Ca application color values of the fruits ranged in the almost the same values with the fruits in the control group (Figure 2A, B, C, D, E). In the observational color assessment, no statistical difference was found in the first year, however, in the following year Pro-Ca was found to be statistically significant $(\mathrm{P}<0.05) \quad$ (Figure 2F). In the both years, observational color values increased with the applications, and the highest percentage of color 

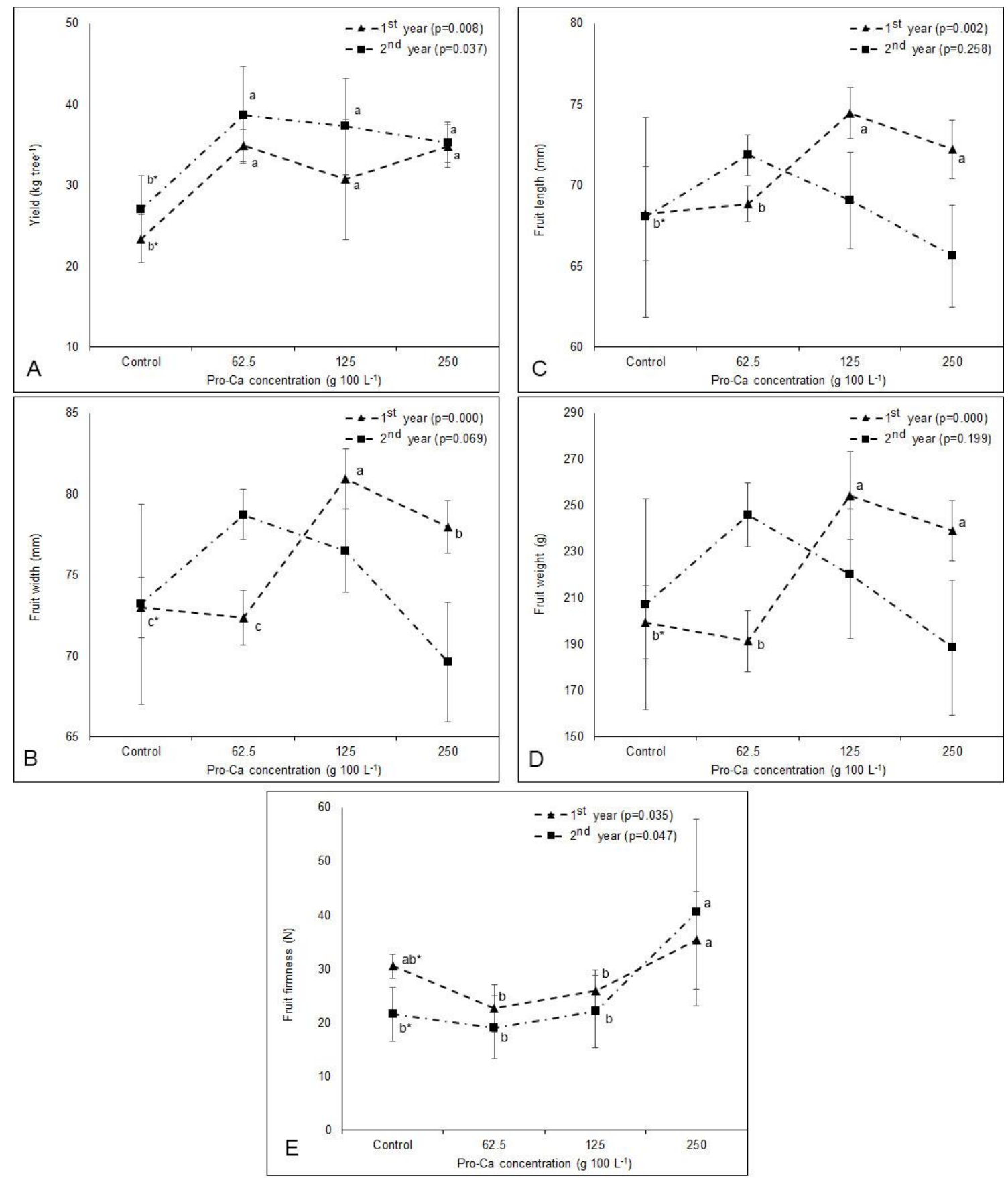

Figure 2. Pro-Ca effects on yield, fruit width, length, weight and fruit firmness in Monroe/GFF 677 (2018 and 2019 ). Data were mean \pm standard deviation. Different letters indicate statistically significant differences among the treatments (LSD, $\mathrm{P}<0.05)$.

Table 2. Effects of Pro-Ca on soluble solid content (SSC), titratable acidity (TA) and pH of Monroe/GFF 677.

\begin{tabular}{lcccccc}
\hline Pro-Ca concentrations & \multicolumn{2}{c}{ SSC $(\%)$} & \multicolumn{2}{c}{ TA $(\%)$} & \multicolumn{1}{c}{$\mathrm{pH}$} \\
\cline { 2 - 7 }$\left(\mathrm{g} 100 \mathrm{~L}^{-1}\right)$ & $1^{\text {st }}$ year & $2^{\text {nd }}$ year & $1^{\text {st }}$ year & $2^{\text {nd }}$ year & $1^{\text {st }}$ year & $2^{\text {nd }}$ year \\
\hline Control & $11.70 \pm 0.36 \mathrm{~b}^{*}$ & $14.28 \pm 0.65$ & $0.46 \pm 0.06 \mathrm{c}^{*}$ & $0.49 \pm 0.12$ & $3.59 \pm 0.11$ & $3.57 \pm 0.11$ \\
62.5 & $11.78 \pm 0.35 \mathrm{~b}$ & $14.63 \pm 0.78$ & $0.51 \pm 0.05 \mathrm{bc}$ & $0.55 \pm 0.15$ & $3.45 \pm 0.06$ & $3.63 \pm 0.05$ \\
125 & $13.75 \pm 0.53 \mathrm{a}$ & $14.08 \pm 1.31$ & $0.58 \pm 0.02 \mathrm{ab}$ & $0.47 \pm 0.09$ & $3.57 \pm 0.21$ & $3.55 \pm 0.10$ \\
250 & $13.00 \pm 0.94 \mathrm{a}$ & $13.90 \pm 1.08$ & $0.64 \pm 0.12 \mathrm{a}$ & $0.54 \pm 0.07$ & $3.22 \pm 0.37$ & $3.57 \pm 0.08$ \\
\hline P values & 0.001 & 0.703 & 0.021 & 0.542 & 0.134 & 0.622 \\
\hline
\end{tabular}

Data were mean \pm standard deviation.

Different letters indicate statistically significant differences among the treatments (LSD, $P<0.05)$. 

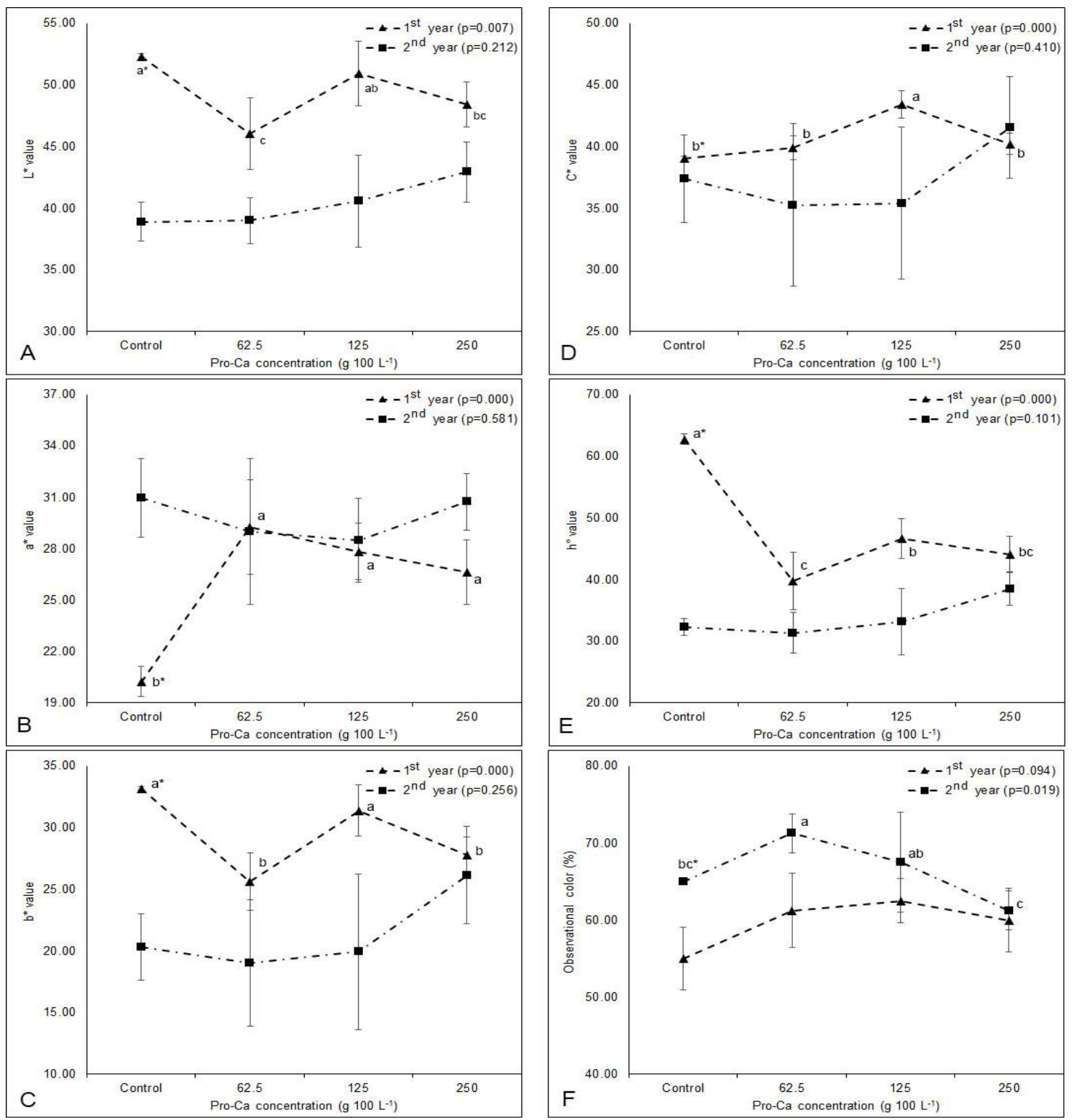

Figure 3. Effects of Pro-Ca on observational color values, $L^{*}, a^{*}, b^{*}, C^{*}, h^{\circ}$ in the Monroe/GFF 677 (2018 and 2019).

Data were mean \pm standard deviation. Different letters indicate statistically significant differences among the treatments (LSD, $\mathrm{P}<0.05)$.

formation was acquired with the Pro-Ca

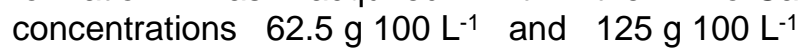
(Figure 2F). Mata et al. (2006) reported that Pro-Ca had no effect on yield and various fruit quality parameters, but only in 'Fuji', a late season cultivar, exhibited a larger percentage of the red. Hence, in current study, Pro-Ca applications were effective on red color formation in the 'Monroe', a late season cultivar.

\section{Conclusions}

Pro-Ca had no negative effect on yield and fruit quality, on the contrary 125 and $250 \mathrm{~g}^{100 \mathrm{~L}^{-1} \text { Pro- }}$ Ca exhibited positive results in important fruit quality such as fruit weight and color. Vegetative shoot development drastically reduced, and also average shoot length compared to the control group reduced by 28 to $32 \%$. Pro-Ca increased 40 to $80 \%$ the average number of nodes with $250{\mathrm{~g} 100 \mathrm{~L}^{-1}}^{-1}$ concentration compared to the control group. With all the results, Pro-Ca applications had positive effects on the vegetative shoot development control and fruit quality in the Monroe/GF677. 125 and/or

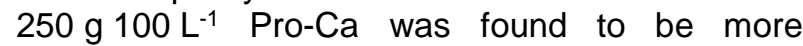
effective than the others.

This study is only a research to determine the Pro applications and their appropriate doses. Especially in the increasingly high density planting peach growing in the world and in Turkey, in the direction of reducing costs and shortening the time of pruning, it is considered to provide additional benefits.

As an alternative to mechanical pruning, chemical pruning can be recommended to apply 125 and / or $250 \mathrm{~g} / 100$ Pro-Ca to peach trees after the shoots are $5 \mathrm{~cm}$ and 3 weeks later (2 times). 


\section{References}

Amarante, C.V.T., Silveira, J.P.G., Steffens, C.A., Freitas, S.T., Mitcham, E.J., \& Miqueloto, A. (2020). Postbloom and preharvest treatment of 'Braeburn' apple trees with prohexadione-calcium and $\mathrm{GA}_{4+7}$ affects vegetative growth and postharvest incidence of calcium-related physiological disorders and decay in the fruit. Scientia Horticulturae, 261:1-9.

Başak, H. (2020). Effects of prohexadione-calcium application methods on seedlings growth and leaf pigmentation in cucumber (Cucumis sativus L.). Erciyes University Journal of Institue of Science and Technology, 36:274-279 (in Turkish).

Beam, J.B., Jordan, D.L., York, A.C., Bailey, J.E., Isleib, T.G., \& Mckemie, T.E. (2002). Interaction of prohexadione calcium with agrichemicals applied to peanut (Arachis hypogaea L.). Peanut Science, 29:29-35.

Beyazıt, S., Imrak, B., \& Küden, A. (2012). Effects of tipping applications on yield and fruit quality of some peach and nectarine. Journal of Agricultural Faculty, MKU, 17:23-30 (in Turkish).

Bilgener, K.Ş., Demirsoy, H., \& Beyhan, N. (1998). Effect of paclobutrazol on vegetative growth and fruit quality of some peaches grown in Samsun. Turkish Journal of Agriculture and Forestry, 22:425-434 (in Turkish).

Byers, R.E., \& Yoder, K.S. (1999). Prohexadione-calcium inhibits apple, but not peach, tree growth, but has little influence on apple fruit thinning or quality. HortScience, 34:1205-1209.

Carra, B., Spagnol, D., Abreu, E.S., Pasa, M.S., Silva, C.P., Hellwig, C.G., \& Fachinello, J.C. (2017). Prohexadione calcium reduces vegetative growth and increases fruit set of 'Smith' pear trees, in Southern Brazil. Bragantia, Campinas, 76:360-371.

Costa, G., Andreotti, C., Bucchi, F., Sabatini, E., Bazzi, C., \& Malaguti, S. (2001). Prohexione-Ca (Apogee $\left.{ }^{\circledR}\right)$. Growth regulation and reduced fire blight incidence in pear. HortScience, 36:931-933.

Costa, G., Sabatini, E., Spinelli, F., Andreotti, C., Spada, G., \& Mazzini, F. (2004). Prohexadione-Ca controls vegetative growth and cropping performance in pear. Acta Horticulturae, 653:127-132.

Coston, D.C., \& Gambrel, C.E. (1984). Controlling excessive peach tree terminal growth. Acta Horticulturae, 146:121-124.

Çetinbaş, M., Butar, S., Atasay, A., İşçi, M., \& Koçal, H. (2015). Reduction of apple vegetative shoot growth cv. Starkrimson Delicious/MM 111 with prohexadione calcium application does not decrease fruit quality. Journal of Applied Botany and Food Quality, 88:259263.

Davis, T.D., Curry, E.A., \& Steffens, G.L. (1991). Chemical regulation of vegetative growth. Critical Reviews in Plant Sciences, 10:151-188.

Davies, P.J. (2004). Plant Hormones: Biosynthesis. Signal Transduction and Action. $3^{\text {rd }}$ edition. Kluwer Academic Publishers. Dordrecht. The Netherlands. $775 \mathrm{p}$.

Duyvelshoff, C., \& Cline, J.A. (2013). Ethephon and prohexadione-calcium influence the flowering, early yield, and vegetatif growth of young 'Northern Spy' apple trees. Scientia Horticulturae, 151:128-134.

Einhorn, T.C., Pasa, M.S., \& Turner, J. (2014). 'D'Anjou' pear shoot growth and return bloom, but not fruit size, are reduced by prohexadione-calcium. Hortscience, 49:180-187.
Elfving, D.C., Lombardini, L., McFerson, J.R., Dreake, S.R., Faubion, D.F., Auvil, T.D., Ee, G.V., \& Visser, D. B. (2003). Effects of directed applications of prohexadionecalcium to tops of mature pear trees on shoot growth, light penetration, pruning and fruit quality. Journal of the American Pomological Society, 57:45-57.

Ergun, N., Çağlar, G., Özbay, N., \& Ergun, M. (2007). Effects of prohexadione-calcium applications on cucumber seedlings quality and plant growth. Bahçe, 36:49-59.

Evans, R.R., Evans, R.E., \& Rademactor, W. (1997). Prohexadione-Calcium for suppression of vegetative growth in eastern apples. Acta Horticulturae, 451:663-666.

Evans, J.R., Evans, R.R., \& Regusci, C.L. (1999). Mode of action, metabolism, and uptake of BAS $125 \mathrm{~W}$ prohexadione-calcium. HortScience, 34:1200-1201.

FAO. 2020. The Food and Agriculture Organization. http://www.fao.org/faostat. Accessed: 04 January 2021.

Graebe, J.E. (1987). Gibberellin biosynthesis and control. A review. Annual Review of Plant Physiology, 38:419465.

Greene, D.W. (2008). The effect of repeat annual applications of prohexadione-calcium on fruit set, return bloom, and fruit size of apples. HortScience, 43:376-379.

Hayashi, T., Heins, R.D., Cameron, A.C., \& Carlson, W.H. (2001). Ethephon influences flowering, height, and branching of several herbaceous perennials. Scientia Horticulturae, 91:305-324.

Hossain, S., Mizutani, F., Onguso, J.M., El-Shereif, A.R., \& Rutto, K.L. (2006). Effect of summer pruning on shoot growth and fruit quality in peach trees trained as Slender Spindle Bush type. Memoirs of the Faculty of Agriculture - Ehime University, 51:9-13.

Ilias, I.F., \& Rajapakse, N. (2005). Prohexadione-calcium affects growth and flowering of petunia and impatiens grown under photoselective films. Scientia Horticulturae, 2:190-202.

Karlovic, K., Vrsěk, I., Sinndrak, Z., \& Zĭdovec, V. (2004). Influence of growth regulators on the height and number of inflorescence shoots in the Chrysanthemum cultivar 'Revert'. Agriculturae Conspectus Scientificus, 69:63-66.

Kaur, S., Gill, M.S., Gill, P.P.S., \& Singh, N.P. (2020). Effect of plant bio-regulators on photosynthesis, growth and yield efficiency of pear trained on Y-trellis system. Journal of Agrometeorology, 22:140-147.

Kim, H.Y., Lee, I.J., Hamayun, M., Kim, J.T., Won, J.G., Hwang, I.C., \& Kim, K.U. (2007). Effect of prohexadione calcium on growth components and endogenous gibberellins contents of rice (Oryza sativa L.). Journal of Agronomy and Crop Science, 193:445-451.

Kofidis, G., Giannakoula, A., \& Ilias, I.F. (2008). Growth, anatomy and chlorophyll fluorescence of coriander plants (Coriandrum sativum L.) treated with prohexadione-calcium and daminozide. Acta Biologica Cracoviensia Series Botanica, 50:55-62.

Lee, I.J., Foster, K.R., \& Morgan, P.W. (1998). Photoperiod control of gibberellin levels and flowering in sorghum. Plant Physiology, 116:1003-1010.

Mata, A.P., Val, J., \& Blanco, A. (2006). Differential effects of prohexadione-calcium on red colour development in 'Royal Gala' and 'Fuji' apples. The Journal of Horticultural Science and Biotechnology, 81:84-88. 
Medjdoub, R., Val, J., \& Blanco, A. (2004). ProhexadioneCa inhibits vegetative growth of 'Smoothee Golden Delicious' apple trees. Scientia Horticulturae, 101:243-253.

Nakayama, I., Kamiya, Y., \& Kobayashi, M. (1990). Effects of a plant-growth regulator. Prohexadione on the biosynthesis of gibberellins in cell-free systems derived from immature seeds. Plant and Cell Physiology, 31:1183-1190.

Özbay, N., Ergun, N. (2015). Prohexadione calcium on the growth and quality of eggplant seedlings. Pesquisa Agropecuária Brasileira, 50:932-938.

Schupp, J.R., Robinson, T.L., Cowgill, W.P., \& Compton, J.M. (2003). Effect of water conditioners and surfactants on vegetative growth control and fruit cracking of 'Empire' apple caused by prohexadionecalcium. HortScience, 68:101-107.

Sugar, D., Elfing, D.C., \& Mielke, E.A. (2004). Effects of prohexadione-calcium on fruit size and return bloom in pear. HortScience, 39:1305-1308.

Treadway, Z.R. (2020). Determining the effect of prohexadione calcium growth regulator on growth and yield of peanut [Arachis hypogaea (L.)] in Mississippi. Master Thesis, Mississippi State University, USA.

Uselis, N., Viškelis, J., Lanauskas, J., Liaudanskas, M., Janulis, V., \& Kviklys, D. (2020). Effects of growth control on yield and fruit quality of the apple cultivar 'Rubin'. Agricultural and Food Science, 29:245-252. 